\title{
FIRST SPECIMEN OF THE NAZCA BOOBY (SULA GRANTI) FOR THE STATE OF BAJA CALIFORNIA, MEXICO
}

JONATHAN VARGAS, Coastal Solutions Fellows Program, Cornell Lab of Ornithology, 159 Sapsucker Road, Ithaca, New York 14850; jnv27@cornell.edu LILIANA ORTIZ-SERRATO and CÉSAR IVÁN MANRÍQUEZ-CASTRO, Pro Esteros A.C., Cuarta 210, Ensenada, Baja California 22800, México; lortiz@ proesteros.org; educacion@proesteros.org

GORGONIO RUIZ-CAMPOS, Colección Ornitológica, Facultad de Ciencias, Universidad Autónoma de Baja California, Carretera Transpeninsular EnsenadaTijuana No. 3917, Colonia Playitas, C.P. 22860, Ensenada, Baja California, México (U.S. mailing address: PMB 064, P.O. Box 189003, Coronado, California 92178); gruiz@uabc.edu.mx (corresponding author)

On 16 June 2021, during the spring-summer monitoring for nesting shorebirds, we found a dead subadult male Nazca Booby (Sula granti, Figure 1) on the inner side of the sandbar at the mouth of the Estero Punta Banda, south of the city of Ensenada, Baja California, Mexico ( $\left.31^{\circ} 46^{\prime} 25^{\prime \prime} \mathrm{N}, 116^{\circ} 37^{\prime} 17^{\prime \prime} \mathrm{W}\right)$. The specimen was found in a site with halophytic plants dominated by Abronia maritima and Carpobrotus edulis. The specimen was identified by its peculiar coral/pink bill with yellower tip in comparison with the yellowish bill color of the Masked Booby, Sula dactylatra (Cuccaro-Díaz et al. 2020). Also, a dorsal view of the central tail feathers shows the white extending from the base of the tail to beyond half its length (Figure 2).

Body measurements of this specimen include total length $784 \mathrm{~mm}$, wingspan $1595 \mathrm{~mm}$, wing chord $430 \mathrm{~mm}$, tarsus length $61.8 \mathrm{~mm}$, tail length $193 \mathrm{~mm}$, bill length $103.6 \mathrm{~mm}$, bill ratio (depth/length $=0.322$ ), and weight $979 \mathrm{~g}$. The weight of the specimen was $41 \%$ less than the mean weight for males ( $1656 \mathrm{~g}$ ) reported for this species in the tropical eastern Pacific (García-R. and López-Victoria 2008), a body condition suggesting starvation as a possible cause of death. The specimen (Figure 3) was cataloged with the number 2165 in the Bird Collection, Vertebrate Laboratory, Faculty of Sciences, Autonomous University of Baja California (UABC).

The Nazca Booby is a marine bird that ranges over the eastern tropical Pacific

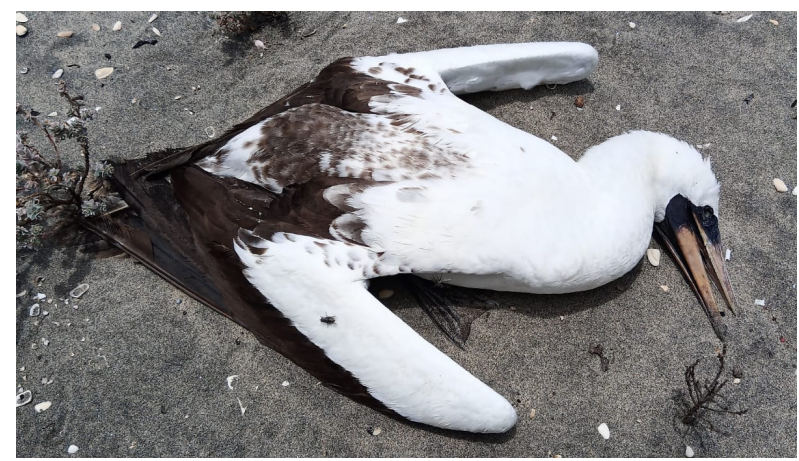

FIGURe 1. Nazca Booby found on 16 June 2021 on the sandbar of Estero Punta Banda, Baja California, Mexico.

Photo by Jonathan Vargas 


\section{NOTES}

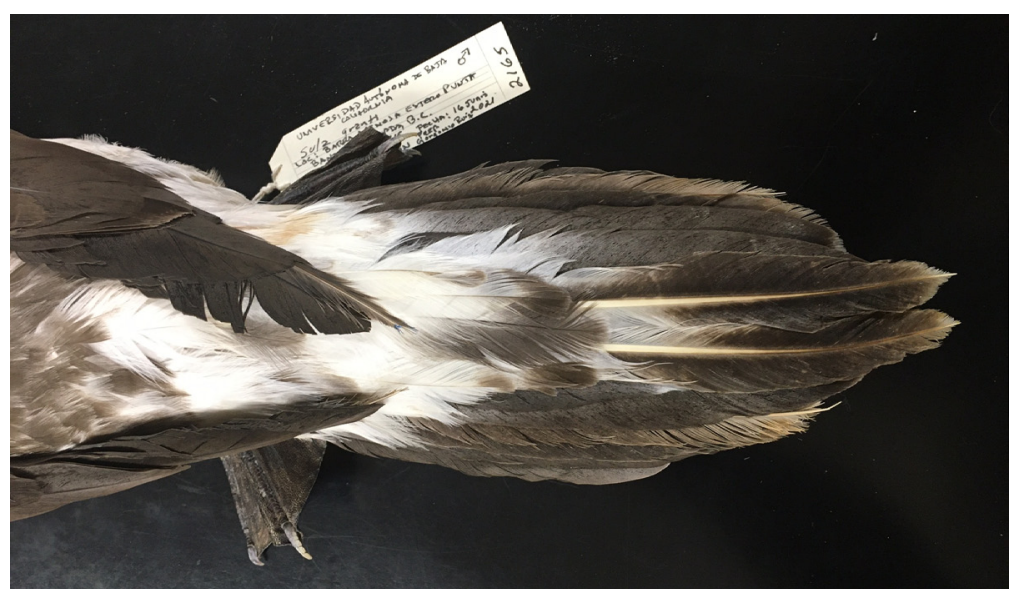

FIGURE 2. Dorsal view of central rectrices showing white extending from the base to beyond the half of length of the tail.

Photo by Gorgonio Ruiz-Campos

Ocean from Mexico to Peru, feeding on fish and breeding primarily on rocky islands, principally the Galapagos and Malpelo islands (Huyvaert and Anderson 2004). However, there are smaller colonies elsewhere, the northernmost on San Benedicto Island (western Mexico), consisting of 4 birds in 1988 and 50 in 1990 (Pitman and Jehl 1998, Cuccaro-Díaz et al. 2020), or possibly the Alijos Rocks, $350 \mathrm{~km}$ west of Cabo San Lázaro, Baja California Sur, where Pitman and Jehl (1988) reported that a few Nazca Boobies were possibly breeding in 1983.

The individual we found represents the first specimen for the Mexican state of Baja California, but there are a few previous sightings. The first record for the state of Baja California was of a subadult that came aboard a boat about $95 \mathrm{~km}$ west of Punta Banda on 27 May 2001 and rode the boat to San Diego, where it was taken into rehabilitation (Garrett and Wilson 2003, Erickson et al. 2013). The earliest report

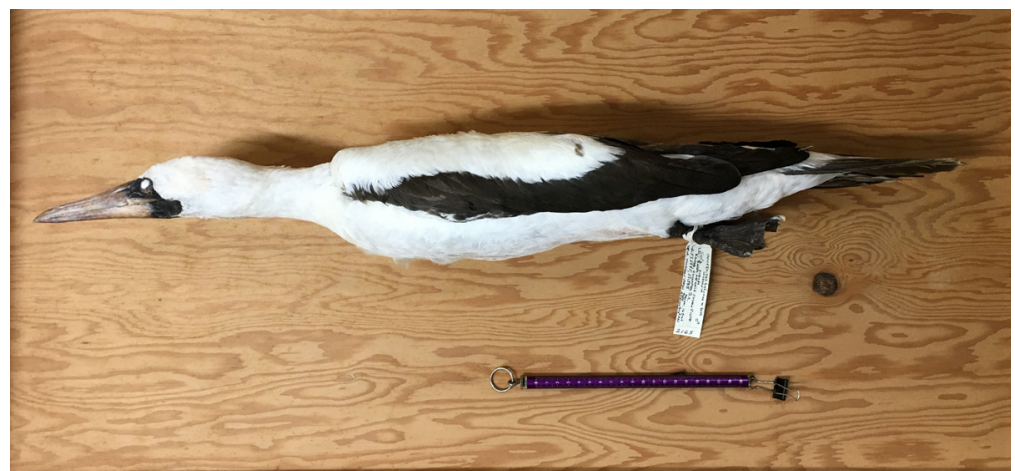

FIGURE 3. Specimen (UABC-2165) deposited in the bird collection of the Universidad Autónoma de Baja California. 
via https://eBird.org is of an adult observed on 17 August 2014 over the Nine Mile Bank, north of the Coronado Islands, just to south of the border with the United States. Since 2014, sightings of the Nazca Booby for the state of Baja California have been reported several times on the citizen-science platforms of eBird $(n=6)$ and https://www.iNaturalist.org ( $n=2$; one redundant with a report to eBird), off the Pacific coast of Baja California. There are no records yet from the Gulf of California side of the state.

In contrast to the few Nazca Booby records for the state of Baja California, in southern California just across the border with the United States, the California Bird Records Committee has accepted 56 records from 2013, year of the first confirmed record (Yang et al. 2016), through 2019. Because of the proliferation of records, that committee has discontinued reviewing reports of this species (Benson et al. 2021). From 2020 through September 2021, 12 additional observations were recorded via eBird. Since the first specimen confirming the Nazca Booby for the United States in 2013, four additional specimens of this species have been preserved from the southern California coast: one at the Los Angeles/Ventura county line in 2018 (Benson et al. 2020; Natural History Museum of Los Angeles County 121174), two from San Diego Bay, on 30 August 2019 and 24 April 2020 [San Diego Natural History Museum (SDNHM) 56365 and 56505, respectively], and one from Imperial Beach on 10 October 2020 (SDNHM 56938). The northernmost Nazca Booby sighted along the Pacific coast was photographed on 30 August 2017, south of the Kenai Peninsula, Alaska (Gibson et al. 2018).

Except at the Alijos Rocks, the well-supported records from even Baja California Sur postdate the year 2000, and the species began to be reported regularly only from 2013 onward, just as in southern Upper California. The recent sightings of Sula granti around the Baja California peninsula and farther north might be explained by warming of oceanic waters caused by climate change, species of tropical affinities extending their ranges north toward warm-temperate latitudes.

We thank Philip Unitt (San Diego Natural History Museum) for information about Nazca Booby specimens and records in California, United States. Kimball L. Garrett and Philip Unitt made very useful comments that improved the content and clarity of this note.

\section{LITERATURE CITED}

Benson, T. A., Fowler, R., McCaskie, G., and Stahl, J. T. 2020. The $44^{\text {th }}$ annual report of the California Bird Records Committee: 2018 records. W. Birds 51:228-260; https://doi.org/10.21199/WB51.3.4.

Benson, T. A., House, D. J., McCaskie, G., Rinkert, A. M., Searcy, A. J., and Terrill, R. S. 2021. The $45^{\text {th }}$ annual report of the California Bird Records Committee: 2019 records. W. Birds 52:2-22; https://doi.org/10.21199/WB52.1.1.

Cuccaro-Díaz, J., Herrera-Gómez, S. A., Galeano, A. M., Del Hoyo, J., Collar, N., and García, E. F. J. 2020. Nazca Booby (Sula granti), version 1.0., in Birds of the World (J. Del Hoyo, A. Elliott, J. Sargatal, D. A. Christie, and E. De Juana, eds.). Cornell Lab Ornithol., Ithaca, NY; https://doi.org/10.2173/bow.nazboo1.01.

Erickson, R. A., Carmona, R., Ruiz-Campos, G., Iliff, M. J., and Billings, M. J. 2013. Annotated checklist of the birds of Baja California and Baja California Sur, second edition. N. Am. Birds 66:582-613.

García-R., S., and López-Victoria, M. 2008. Diferencias entre sexos en el tamaño corporal y la dieta en el piquero de Nazca (Sula granti). Ornitología Colombiana 7:59-65.

Garrett, K. L., and Wilson, J. C. 2003. Report of the California Bird Records Committee: 2001 records. W. Birds 34:15-41.

Gibson, D. D., DeCicco, L. H., Gill, R. E. Jr., Heinl, S. C., Lang, A. J., Tobish, T. G. 


\section{NOTES}

Jr., and Withrow, J. J. 2018. Fourth report of the Alaska Checklist Committee, 2013-2017. W. Birds 49:174-191; https://doi.org/10.21199/WB49.3.1.

Huyvaert, K. P., and Anderson, D. J. 2004. Limited dispersal by Nazca Boobies Sula granti. J. Avian Biol. 35:46-53; https://doi.org/10.1111/j.09088857.2004.03131.x.

Pitman, R. L., and Jehl, J. R. Jr. 1998. Geographic variation and reassessment of species limits in the "Masked" boobies of the eastern Pacific Ocean. Wilson Bull. 110:155-170.

Yang, D. S., Rottenborn, S. C., Terrill, S., Searcy, A. J., and Villablanca, F. X. 2016. First California records of the Little Stint and Nazca Booby confirmed through molecular analysis. W. Birds 47:58-66.

Accepted 16 November 2021 Associate editor: Christopher W. Swarth 